Historic, Archive Document

Do not assume content reflects current scientific knowledge, policies, or practices. 



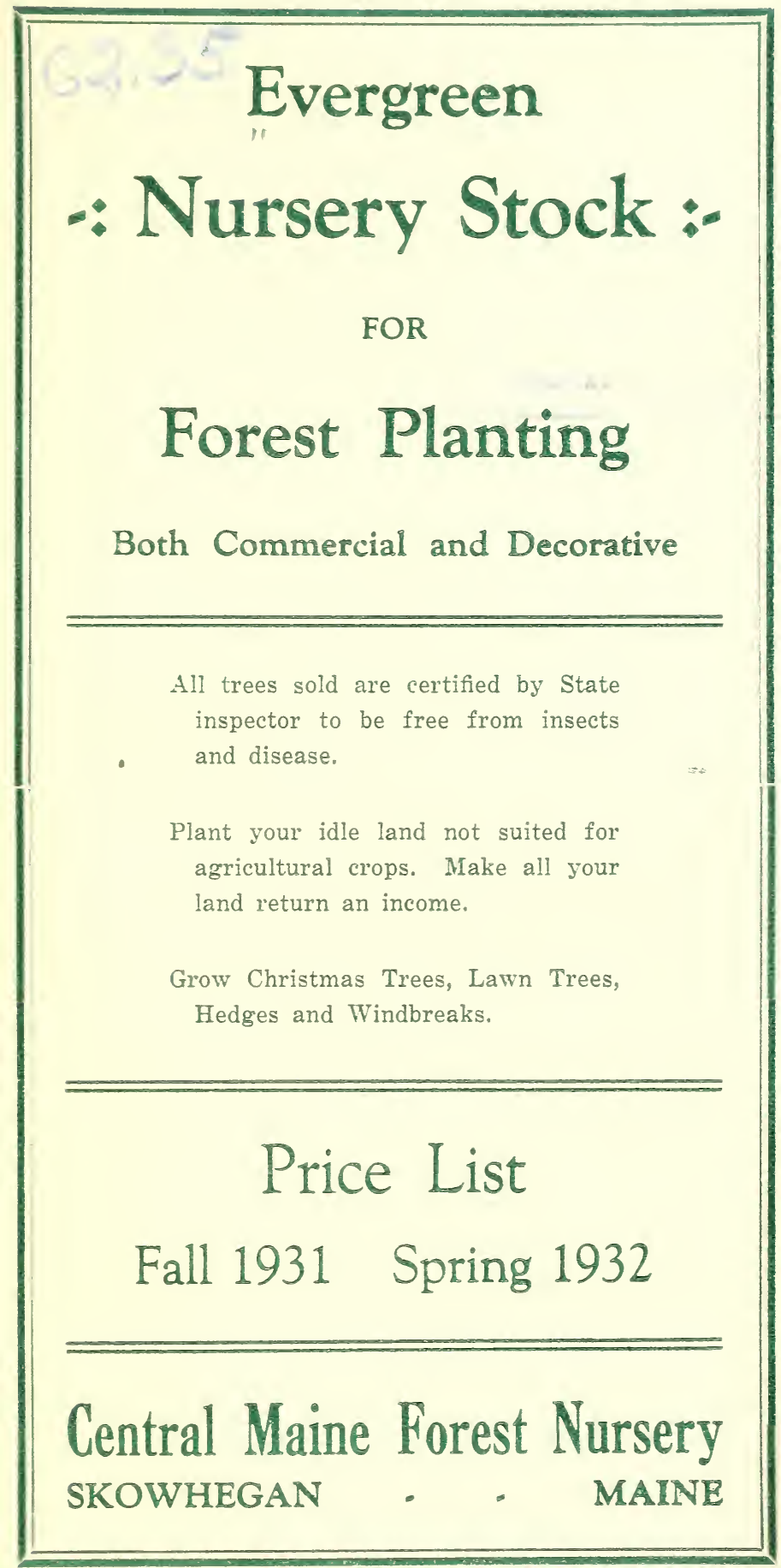




\section{WHITE PINE*}

3-year seedlings

\begin{tabular}{rrrrr} 
Age & \multicolumn{1}{c}{ Size } & \multicolumn{2}{l}{ Per M Per C Each } \\
$3-0$ & $5-8$ in. & $\$ 5.00$ & $\$ 1.00$ & \\
$2-1$ & $4-8$ in. & 10.50 & 1.40 & \\
$2-2$ & $6-12$ in. & 16.00 & 2.10 & \\
$2-3$ & $12-18$ in. & 25.00 & 4.00 & \\
$2-4$ & $18-24$ in. & 50.00 & 8.00 & $\$ .15$ \\
& $2-3$ ft. & & 100.00 & 1.00 \\
$4-5$ & ft. & & 190.00 & 2.00
\end{tabular}

3-year transplants

4-year transplants

5-year transplants

6-year transplants

Several times transplanted 4-5 $\mathrm{ft}$.

*White Pine can be hipped in the New England States and New York only.

SCOTCH PINE

\begin{tabular}{|c|c|c|c|c|c|}
\hline 3-year transplants & $2-1$ & $3-6$ in. & $\$ 12.00$ & $\$ 1.60$ & \\
\hline 5-year transplants & $2-3$ & $6-12$ in. & 16.00 & 2.10 & \\
\hline 6-year transplants & $2-4$ & $18-24$ in. & 90.00 & 12.00 & \\
\hline everal times transp & & $\begin{array}{l}2-3 \mathrm{ft} . \\
4-5 \mathrm{ft} .\end{array}$ & & $\begin{array}{r}95.00 \\
190.00\end{array}$ & $\begin{array}{r}\$ 1.00 \\
2.00\end{array}$ \\
\hline
\end{tabular}

\section{RED PINE}

\begin{tabular}{|c|c|c|c|c|}
\hline 3-year seedlings & $3-5$ in. & $\$ 6.00$ & $\$ 1.25$ & \\
\hline 4-year transplants & $3-5$ in. & 12.00 & 1.60 & \\
\hline year transplants, twice trans. $2-3-1$ & $9-12$ in. & 30.00 & 4.00 & \\
\hline everal times transplanted & $\begin{array}{l}3-4 \mathrm{ft} \\
5-6 \mathrm{ft}\end{array}$ & & & $\begin{array}{r}-\$ 1.50 \\
3.00\end{array}$ \\
\hline
\end{tabular}

\section{MUGHO PINE}

3-year seedlings

4.year transplants

4-year transplants

6-year transplants

7-year transplants, twice trans. 2-3-2

\begin{tabular}{|c|c|c|c|}
\hline Age & Size & Per $\mathbf{M}$ & Per C Each \\
\hline $3-0$ & & $\$ 12.00$ & $\$ 2.00$ \\
\hline $3-1$ & & 30.00 & 4.00 \\
\hline $2-2$ & $4-6$ in. & 60.00 & 8.00 \\
\hline $2-4$ & $6-10$ in. & 100.00 & 12.00 \\
\hline-2 & & 120.00 & 15.00 \\
\hline
\end{tabular}

\section{AUSTRIAN PINE}

\begin{tabular}{lrrr} 
Age & \multicolumn{1}{c}{ Size } & \multicolumn{2}{c}{ Per M Per C Each } \\
$2-1$ & $3-5$ in. $\$ 30.00$ & $\$ 4.00$ \\
$2-2$ & $5-9$ in. & 40.00 & 5.00 \\
$2-3$ & $6-10$ in. & 50.00 & 6.00 \\
$2-4$ & $10-16$ in. 80.00 & 14.00
\end{tabular}

Special BARGAIN on all White Pine Seedings and transplants, also on White Spruce and Norway Spruce Seedlings when purchased in quantites. Write for Special Bargain Prices on these varieties. 


\section{NORWAY SPRUCE}

\begin{tabular}{|c|c|c|c|c|c|}
\hline & Age & Size & Per M & Per C & E Each \\
\hline 3-year seedlings & $3-0$ & $3-5$ in. & $\$ 4.00$ & $\$ 1.00$ & \\
\hline 3-year transplants & $2-1$ & $3-5$ in. & 12.00 & 1.60 & \\
\hline 4-year transplants & $2-2$ & $5-10$ in. & 18.00 & 3.00 & \\
\hline 7-year transplants & $2-5$ & $12-18$ in. & 100.00 & 12.50 & \\
\hline 8-10-year transplants & & $2-3 \mathrm{ft}$. & & 95.00 & 1.00 \\
\hline
\end{tabular}

\section{WHITE SPRUCE}

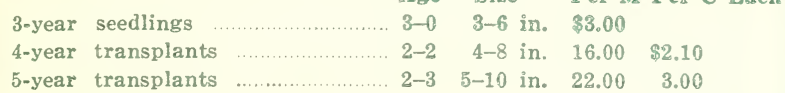

\section{COLORADO BLUE SPRUCE}

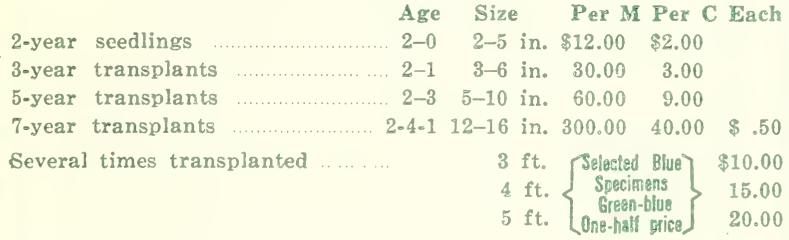

\section{BALSAM FIR}

4-year transplants 5-year transplants 2-foot bushy

$$
\begin{array}{lcrc}
\text { Age } & \text { Size } & \text { Per M Per C Each } \\
2-2 & 4-8 \text { in. } \$ 20.00 & \$ 3.00 \\
2-3 & 6-12 \text { in. } 50.00 & 9.00
\end{array}
$$

\begin{tabular}{|c|c|c|c|}
\hline Age & Size & Per M & Per C Each \\
\hline $2-$ & $2-5$ in. & $\$ 20.00$ & $\$ 3.00$ \\
\hline $2-2$ & $4-8$ in. & 23.00 & 3.50 \\
\hline
\end{tabular}

3-year transplants

4-year transplants

\section{ARBORVITAE-WHITE CEDAR}

3-year seedlings

$\begin{array}{llcc}\text { Age } & \text { Size } & \text { Per M Per C Each } \\ 3-0 & & \$ 7.00 & \$ 1.00 \\ 2-2 & 3-6 \text { in. } & 25.00 & 4.00 \\ 2-3 & 4-8 \text { in. } & 35.00 & 5.00\end{array}$

4-year transplants

2-3 $4-8$ in. $35.00 \quad 5.00$

The above prices are F. O. B. Skowhegan, Maine. Cash with order or satisfactory references required from parties unknown to us. Orders to be shipped C. O. D. must be accompanied by a $25 \%$ deposit. When orders are for less than 1,000 trees or stock is 18 inches or over in height, a nominal packing charge will be made. 
We furnish our stock at the lowest prices made possible by mass production. We have larger sizes and various species other than those listed which we will gladly quote on application.

Orders for less than 50 trees are sold at the piece rate, 50 to 500 at 100 rate, over 500 at 1,000 rate.

Orders for fall delivery can be shipped September 15 th to November 1st. Orders for spring delivery, April 25th to June 1st.

\section{Watch}

1. Take the trees out of the boxes These

\section{Points} as soon as possible after arrival, untie the bundles and "heel in" the trees. This is done by placing the roots in a trench 5-6 inches deep and covering with cool, moist soil. The trenches should also be in a cool shady spot. The trees will keep this way for several days but it is always best to set out the trees as soon as possible after arrival.

2. Keep the roots moist at all times while planting by carrying the trees in a pail with water or wet moss in the bottom. Never let them dry out. If they do dry out, throw the plants away at once and do not go to the trouble and expense of planting them. Dead trees cannot be revived by planting.

3. Take pains to have the holes dug deep enough to hold the roots of the plants without cramping or upbending.

4. See to it that the plants are set upright and the soil pressed firmly around the newly planted trees. This can be done most effectively with the heel, taking care not to injure or bark the stock in the process. When left the soil should be a little higher than the general level, as it is liable to settle later.

5. Spacing is usually six by six feet apart, in rows, the distances being paced rather than actually measured. This will require from 1,000 to 1,200 trees to the acre according to how regularly the spacing is done.

\section{Central Maine Forest Nursery SKOWHEGAN, MAINE}

